\title{
Confucian Concept of Self-Cultivation and Social Harmony
}

\author{
FAHRUR ROZI \\ Univ. Lille, CNRS, UMR 8163 - STL- Savoirs Textes Langage, F-59000 \\ Lille, France; Islamic Institute of Imam Ghozali (IAIIG), Cilacap, Indonesia \\ (Awardee 5000 Doctor LN Kementerian Agama RI)
}

\begin{abstract}
This study highlights the notion of self-cultivation, one of the most important heritages of Confucianism with regard to social harmony. Self-cultivation is the first step for developing society, namely how people should develop the self as a basis for developing family, society and the world. The basis of self-cultivation is ren (humanity). If we can conduct it correctly, then this will lead to social harmony and peace in-practice.

Social harmony presupposes diversity. Diversity is an impirical reality. Hence, tolerance in diversity is needed. It is the basis of a family ethics and an ideal society. So, in the process of harmonization, there is always a dialogical of understanding between the self and the others based on their role and position. This is related to the another concept of Confucius, that of rectifying names. This is the epistemological foundation. It is not only a theoretical matter, but also a practical one. The objective of such a notion is for people to be aware of their position, role and obligations as a part of society. Therefore, self-cultivation allows for correctness of name, and it is the base for positive relation in the family and society. Briefly, self-cultivation is the correct way to realize the great harmony in reality and one of the solutions for socio-political problems. There is no harmony without diversity.
\end{abstract}

Key words : Self-cultivation, Rectification of Names, Harmony, Peace.

\section{A. Introduction}

The most important topic in Confucianism is self-cultivation and social harmony. Discussing self-cultivation presupposes an understanding of social harmony. It concerns umans existence and humankind' survival in the world. It invoves identifying one's proper position and obligation as a human being, and then how to reach harmony and peace in daily social life by carrying out self-cultivation based on humanity (ren). Any discussion about harmony and peace entails one about diversity and mutual relationships. This article will engage with the topic of self-cultivation and social harmony. It is at the forefront of the Chinese cultural tradition which developed more than 2500 years ago and continued to the present. Self-cultivation and social harmony are two concepts of Confucius which have made a valuable contribution to humans civilization and development in the world.

In fact, the main concern of Confucianism contains the wisdom that can be used to achieve an equitable and prosperous world. In Confucianism, human beings are the center of the universe. Human beings and their expression of humanity (ren) are the root of social relationship. This anthropocentric understanding of Confucianism leads us to understand that human being can not live alone. As Tu Wei-Ming ${ }^{1}$ said, this concern for the concreteness of the life-world emphasises the social dimension of the human condition. This allows for the group to take precedence over conceptions of the individual self. Confucius' humanism tends to incorporate the spiritual and natural dimensions in a comprehensive and integrated vision of the nature and function of humanity in the cosmos. Thus, in this context, embarking on a proper and sincere self-cultivation is the starting point for achieving the true happiness of human beings. By positioning self-cultivation as a starting point, Confucianism develops the concept of harmony that is needed in the pursuit of happiness, peace, and prosperity.

\section{B. Self-Cultivation}

The title of this article, "Confucian Concept of Self-cultivation and Social Harmony' is chosen for a specific purpose. Self-cultivation and social harmony are two of the greatest original ideas of Confucius as we can find them in The Great Learning ${ }^{2}$ (chapter primary, 6), ' From the Son of Heaven down to the mass of the people, all must consider the self-cultivation as the root of everything", and in The Doctrine of the Mean ${ }^{3}$ (chapter XIX, 7),

\footnotetext{
1. Tu Wei-Ming, Self-cultivation in Chinese philosophy, DOI, 10.4324/9780415249126-G014-1

2. Si Shu, 2012, 7, Si Shu (Kitab Yang Empat), Kitab Suci Agama Khonghucu, Majelis Tinggi Agama Khonghucu Indonesia (MATAKIN), Jakarta.

3. Si Shu, 2012, 36, Si Shu (Kitab Yang Empat), Kitab Suci Agama Khonghucu, Majelis Tinggi Agama Khonghucu Indonesia (MATAKIN), Jakarta.
} 
"Hence the sovereign may not neglect the cultivation of his own character. Wishing to cultivate his character, he may not neglect to serve his parents. In order to serve his parents, he may not neglect to acquire knowledge of men. In order to know men, he may not dispense with a knowledge of Heaven", and in The Doctrine of the Mean ${ }^{4}$ (chapter XIV, 2), it is said in the Book of Poetry, "Happy union with wife and children is like the music of lutes and harps. When there is concord among brethren, the harmony is delightful and enduring. Thus may you regulate your family, and enjoy the pleasure of your wife and children."

Furthermore, self-cultivation will lead a person to engage in good interactions with the others. Self-cultivation is the basis for governing the state and bringing peace to the world ${ }^{5}$. Self-cultivation leads people to have the virtues of honesty, sincerity, empathy, and related qualities. The point is to come to humanity, with an ethical attitude in relation and interaction with the others ${ }^{6}$. This interaction aiming at self-cultivation should be carried out consistenly. Cyrille J.D Jawary said that the self-cultivation is «bien plutôt la recherche tenace d'un développement progressif de cette aptitude qui pousse les humains vers le bien tant pour eux-mêmes que pour les autres ${ }^{7}$. The main aim of Confucius' notion is not only to set the meaning of the notion of self-cultivation, but to put this notion to work, so that to every person becomes chun tzu (pinyin : junzi), translated variously as an exemplary person or morally noble human being. The results of this aim is attaining a good family relationship and a good social relationship or in the Confucianism context, the great harmony.

Self-cultivation is the premier step to become a morally noble human (chun tzu) before regulating family, society and state. It is an obligation for everyone and each person in the state, as we can find it in The Great Learning, (verse 6): 'From the Son of Heaven down to the mass of the people, all must consider the cultivation of the person the root of everything besides." ${ }^{, 8}$. Self-cultivation is a personal ethics that give contribution to participate in social harmony ${ }^{9}$. Self-cultivation is not something we practice for our private satisfaction or because it leads us to some sort of enlightenment. It is meant to allow us to act, and act properly, in our family, our neighborhood, and our country ${ }^{10}$.

A productive self-cultivation will lead people to an improved self-esteem and better behavior. This, flows on to family, society, and government in beneficial outlook and actions. And finally, it leads to a peaceful world. Peace in the world will not be able to be achieved if there is no harmony in what the Confucian concept takes to be the minimal unity of social cohesion, namely family. A peaceful country is only possible when the people are in peace. Peaceful society is only possible when the families are in peace ${ }^{11}$. Peaceful families only possible if each member of the family understands their rights and obligations, based on the good of self-cultivation. So, we believe that our society would be better if we talked about self-cultivation. Self-cultivation allows the presence of genuine friendships interaction between all members of society.

The procedure of self-cultivation as described in The Great Learning is wishing to cultivate the self requires that, one should first rectify one's heart. Wishing to rectify one's heart, one should first seek to be sincere in one's thoughts. Wishing to be sincere in one's thoughts, one should first extend to the utmost one's knowledge. Such extension of knowledge lies in the investigation of things ${ }^{12}$.

We can say that self-cultivation is a personal ethics which reflects family ethics and social ethics. That a human | being is called a human being when he or she is in a considerate relationship with other human beings. $L i$ (propriety) is the basis of social ethics. That thought leads us to understand that peace in the world will not be achieved if there is no harmony in the family, and that it has to be started from the self, as the smallest unit of society.

In Confucianism, self-cultivation is the important base to present justice and peace, because the foundation of selfcultivation is ren (humanity). Confucian ethics are based on human relationship within society.

\footnotetext{
${ }^{4}$. Si Shu, 2012, 31, Si Shu (Kitab Yang Empat), Kitab Suci Agama Khonghucu, Majelis Tinggi Agama Khonghucu Indonesia (MATAKIN), Jakarta.

5. Xinzhong Yao, 1999, p 4., Confucianism and its Modern Values: Confucian moral, educational and spiritual heritages revisited, Journal of Beliefs \& Values, Vol. 20, No. 1.

6. Lee Dian Rainey, 2010, p 198, Confucius \& Confucianism, The Essentials, Blackwell, UK.

7. Cyrille J D Jawary, Les Trois Sagesses Chinoises, Taoisme, Confucianisme, Budhisme, 2010 :

8 . The Great Learning, verse 6.

9. Loubna El Amine, 2015, p 151, Classical Confucian political thought : A new interpretation, Princeton University Press, Princeton, New Jersey, 2015.

10. Lee Dian Rainey, 2010, p 198, Confucius \& Confucianism, The Essentials, Blackwell, UK.

11. The Great Learning of Confucius, verse 4 - 5.

12. Thomas Hosuck Kang, 1997, p 60, Confucius and Confucianism, Questions and Answers, Confucian Publications, Washington, D.C.
} 
This distinguishes Confucian ethics from those in the West which are based on human existence personally and individually. In this context, Thomas Hosuck Kang explained the Confucian concept as a relation system, or a concept of belonging : "Human being to human being; human being to family; human being to community; human being to society; human being to the state, and human being to the world, human being to the universe. Confucius was, in a sense, the father of Oriental ethics, Oriental philosophy, Oriental sociology, Oriental anthropology, and many other fields. In contrast with Western ethics is based on personal and individual human beings who are only related to God, Confucian ethics is based on human beings in the community and society. Human beings are thinkable only in the relation of humans being. Hence, without community and society, human beings cannot exist"13. The family system is the micro-structure of the world. The family is a castle of human beings. Without the family there is no society. The family is the root of the human race, while the world is a macro-structure of the family ${ }^{14}$.

\section{The Rectification of Names}

The rectification of names is central to understanding the great harmony in Confucianism or rational coordination of social interaction. The question that must be answered is how can the Confucian social concept of the rectification of names be developed or implemented to build some means of achieving unity in the presence of cultural diversity?

The rectification of names, namely designating names appropriately and matching these names to actions such that every single name has a set of responsibilities attached to ensure the harmony. To put it in another way, rectifying names aims to establishing correct names and their correct use for the reason that they are the base of an ideal society, while incorrect names and incorrect use of names are the sources out of which grow problems of linguistic, moral, social and political disorder. Names are also a medium for interaction without which the division of labour would be imposible. A name makes posible not only the survival of the human species, but also the progress of civilizational development ${ }^{15}$. So, the correctness of names involved by rectifying names is not only a theoretical matter, but it is more a practical matter ${ }^{16}$. Indeed, the objective of such notion is that people be aware of their position, function and obligations as a part of society.

The use of a name is correct when it is used in a way corresponding to the meaning of the name. And the meaning of a name is established by some public norms of social actions. So, if there is no conformity between the norms that establish the meaning of the name and the attitude or behavior of the people, we say it is not correct. The important point is that from the perspective of Confucianism those norms that establish meaning, because of their social character, are a crucial constitutive of the social institutions. For instance, we can judge or evaluate if a leader behaves as a leader only if we evaluate his or her_behavior within the context of the norms that establish the meaning of being leader. In a similar way, a minister should reflect the reflect the attitude and behavior of a minister, a father should reflect the attitude and behavior of a father, and a son should reflect the reflect the attitude and behavior of a $\operatorname{son}^{17}$. Briefly, the correctness of names according to Confucius is the foundation of the great universal harmony. This leads us to ethical components based on the pragmatist theory of meaning.

So, if the use of names is correct and interrelation between names themselves is also correct, then an authentic harmony will. Furthermore, the correctness of names is not about truth and falsehood in the truth-functional sense of formal semantics, but about taking responsibility for what we do and giving reasons for doing so. In fact, Confucius' concept of the use of names was triggered by a situation which occured during the social and political disorder in China at his period of history. According to Confucius, this condition occured because the rulers, the ministers, and people acted in ways that not in accordance with the position they occupied. What they said was not same as what they did, such as a minister not behaving as one.

The interesting point in Confucius' notion of the correctness of names is that there is interdependence between a single name and another names. So, in some sense, this form of holism also extends the notion of harmony. The correctness of a single name has to be integrated with the correctness of other names.

\footnotetext{
${ }^{13}$. Thomas Hosuck Kang, 1997, p 109, Confucius and Confucianism, Questions and Answers, Confucian Publications, Washington, D. C.

${ }_{15}^{14}$. Thomas Hosuck Kang, 1997, p 60.

15. Tsung-I Dow, p, 125, The Twofold Phenomenon In Naming: A Reflection From The Confucian-Taoist Yin-Yang Dialectical, Monistic Perspective.

${ }_{16}^{16}$. John Knoblock, p, 601, Xunzi, A Translation and Study of the Complete Works, Volume 2.

${ }^{17}$. The Analects of Confucius(version 2.2), Robert Eno (translator), 2015, XII, 11, p 62. See Thomas Housck Kang, 1997, p 111 : There are basically five human relationships: parents and children; the ruler and subject and the people; husband and wife or man and woman; elder and younger or elder brother and younger brother; friend and friend.
} 
That is why Confucius mentioned names in the plural form, not in singular form when he answered Zilu's question ${ }^{18}$. In other words, a single name cannot be correct independently, separated from the correctness of other names. There is dialogical understanding between names themselves; that is, if someone uses a name it has to respond to the intended use of the name as well as relating this use to the use of other names. Hence, there is a harmony here, harmony between the names themselves. Harmony always contains diversity. Harmony cannot exist without diversity. So, in this context, harmony is not only the objective of the correctness of names, but it is also a paradigm, it is an episteme.

Confucius' notion of the correctness of names has derived a notion of social order and peace. Both social order and peace are prerequisite for gathering harmony. Human beings can not exist on their own. They have to be able to make a social relationship with another human being. How to make a social relationship depends on a person's behavior towards others in daily life. And how to behave towards others is how to know and have humanity. In the view of this article, this is the meaning of the great harmony of Confucius. Good relationships between people is the key to reach the great harmony and peace. But, the first thing to be done for achieving all of them is selfcultivation. It is instructive to look at the experiences of Indonesia on the theme of harmony in social life, especially from the perspective of_Confucian adherents.

\section{Confucianism In Indonesia}

Confucianism came to Indonesia along with the arrival of Chinese merchants and immigrants around the 3rd Century BC ${ }^{19}$. But, from 1967 until 2000, based on the Presidential Instruction (Inpres/Instruksi Presiden) No. 14/1967, Confucianism in Indonesia was derecognized and suppressed. This regulation practically banned the practice of Chinese culture, the expression of Chinese traditional beliefs, and Chinese celebrations and festivities. In short, all things Chinese-affiliated were targetted. This certainly took its toll on Confucianism in Indonesia, as it was considered a Chinese faith ${ }^{20}$. But, there were no protests or demonstration by Confucian adherents to oppose the government. They obeyed the government's decision. This indicated their expression of loyalty to the government because that was precisely the teachings of Confucianism. _They attempted to realize the harmony in social life with their high tolerance.

| Then, the political situation changed. The era of the New Order (in Bahasa Indonesia : Orde Baru) was overtaken by the Reformation era. And since 2000, Confucianism's official status was that of a religion. This was based on the Presidential Decision (Keppres/Keputusan Presiden) No. 6/2000 under the president KH. Abdurrahman Wahid. This regulation abrogated the Presidential Instruction (Inpres) No. 14/1967. Moreover, the Presidential Decision (Keppres) No. 19/2002 has been acknowledging the Imlek (Chinese new year/Confucian holiday) as a national holiday. Thus Confucianism has the same official status as other religions under the jurisdiction of the Ministry of Religious Affairs, these being Islam, Catholicism, Christianity (the term used for Protestants), Hinduism and Buddhism, The official organization representing Confucianism in Indonesia is MATAKIN (Majelis Tinggi Agama Khonghucu Indonesia/The Supreme Council for the Confucian Religion in Indonesia).

What the president Gus Dur had done was based on the Pancasila. This is the official and foundational philosophical theory of Indonesia. Pancasila comprises two words originally derived from Sanskrit: 'panca' (five) and 'silla' (principles). Pancasila is composed of five principles and contends that they are inseparable and interrelated. The five principles are the universal principles based on : Bhinneka Tunggal Ika or Unity in Diversity. They are as follows :

1. Belief in the One and Only God ("Ketuhanan Yang Maha Esa")

2. A Just and Civilized Humanity ("Kemanusiaan yang Adil dan Beradab")

3. The Unity of Indonesia ("Persatuan Indonesia")

4. Democracy guided by the inner wisdom in the unanimity arising out of deliberations amongst representatives ("Kerakyatan yang dipimpin oleh Hikmat Kebijaksanaan dalam permusyawaratan/perwakilan")

5. Social justice for the whole of the people of Indonesia ("Keadilan Sosial bagi seluruh Rakyat Indonesia")

These principles were taught in schools under the guidance and direction of the government. However, as time and growing prosperity weakened the need for such education, the Pancasila ideals became less emphasized.

Although Confucianism came to Indonesia thousands of years ago, most of the Confucianism adherents in Indonesia are ethnic Chinese. This is so because Confucianism is not a missionary faith such as Islam and

\footnotetext{
${ }^{18}$. The Analects of Confucius (version 2.2), Robert Eno (translator), 2015, XIII, 3, p 67. Zilu said, "If the ruler of Wei were to entrust you with governance of his state, what would be your first priority." The Master said, "Most certainly, it would be to rectify names". Robert Eno give a notice : This states one facet of what is known as the doctrine of the "rectification of names".

19. Setiawan, Chandra, 1998, 49, Kehadiran Agama Khonghucu Di Indonesia, Matakin, Jakarta.

${ }^{20}$. Yan, Heriyanto, 2005, 2. The history and legal position of Confucianism in post-independence Indonesia. 
Catholicism/Christianity. Confucianism emphasizes the moral teaching rather than religious conversion. Hence, anyone can become a Confucian as long as their behavior is in accordance with the moral teachings of Confucius. This is particularly favored by some boards of MATAKIN.

\section{E. The Great Harmony}

What is the meaning of harmony according to Confucianism-? Problems in social life are very complex. One of the social problems is identity crisis. This occurs because of incomplete self-cultivation. A person does not know their role and position. Their behavio is not in accordance with the name they bear. Human beings lose their grip on living. In addition, the establishment of religious beliefs is crushed by a materialistic ideology. This refers to the belief that the material is the only measure and standard of truth, while religious beliefs or spirituality are regarded as nothing more than a secondary need to meet the demands of social life.

A return to religious spirituality may occur under the pressure of anxiety Religious spirituality has been tested and shown capable of providing comfort and understanding for people in need. this means that religion actually has the ability to provide a sense of calm and security, giving a real identity, thus providing humans a meaning to their existence.

We can acquire the right knowledge about human nature only when we consider it as a system of social life and study it from an ever-evolving and comprehensive point of view. We must analyze it from its social position and relations, as social life is the essential quality of human existence. This does not mean that Confucius did not consider the role of individual free will. As Thomas Hosuck Kang said, human beings are capable of being thought about only in relationship to other human beings ${ }^{21}$. According to Confucius, names are related to all social dimensions and Confucius had a serious concern with regard to individuality and sociality for advancing social older and harmony through human relationships. Thomas Hosuck Kang has claimed that Confucius was historically the first one who discovered this concept ${ }^{22}$.

The nature of a human being comprises three elements: (1) the position of nature, namely the human being is as a personal being and creation of God; (2) the composition of nature, namely the human being consists of soul and body; and (3) nature of nature, namely the human being lives as an individual being and a social being. Each of them is a mono-dualist, the two being united. The three mono-dualisms_are united in what is called a monopluralist, unified pluralism ${ }^{23}$. This means that all aspects within a human being must operate in a harmonious, fair and balanced way because each person has rights to be fulfilled. The goal of human life is to achieve godly character. In the context of Confucianism, godly character relates to becoming a chun tzu (an exemplary person).

The balance of the relationship between body and soul is complementary such as melodies in music, namely they affirm_and complement one another. This balance leads to harmony of the individual-social relationship which will be followed by the chun tzu experience. Hence, the concepts of harmony and balance which in Eastern thought are central. This points to the appropriateness of working with ideals and self potential. Philosophically, harmony presupposes the existence of different things and implies a certain favorable relationship among them ${ }^{24}$.

In Confucianism, a human can only be called a human if a human being is able to establish good relations with other humans. This means that human existence depends on the extent to which a person humanizes others, respects others, upholds the dignity of humanity. This is explained in the Analects of Confucius. If a person wants to advance cannot do so alone, they must also advance others. When you go out your front gate, continue to treat each person as though receiving an honored guest. When directing the actions of sub-ordinates, do so as though officiating at a great ritual sacrifice. Do not do to others what you would not wish done to you. Then, there can be no complaint against you, in your state or in your household ${ }^{25}$. What you would not wish done to you, then do not do it to others, because in the world with-in the four seas, all men are his brothers ${ }^{26}$. This is the meaning of humanity (ren) of Confucianism.

The concept of ren as the core of Confucian moral teaching is the true humanity which every human being possesses. It is the fundamental characteristic which is reflected in human actions. Ren also refers to benevolence. Benevolence means to love humankind. Human beings should follow the humanitarian spirit and start from the self

\footnotetext{
${ }^{21}$. Thomas Hosuck Kang, 1997, p 109, Confucius and Confucianism, Questions and Answers, Confucian Publications, Washington, D.C.

22. Thomas Hosuck Kang, 1997, p 111, Confucius and Confucianism, Questions and Answers, Confucian Publications, Washington, D.C.

23. Notonagoro, 1997, p 13, Pancasila Secara Ilmiah Populer, Bumi Aksara, Jakarta.

24. Chenyang Li, 2006, p 584, The Confucian Ideal of Harmony, in Philosophy East and West, Volume 56, Number 4, October 2006, pp. The University of Hawaii Press.

25. The Analects of Confucius (version 2.2), Robert Eno (translator), 2015, XII, 2, p 62.

${ }^{26}$. The Analects of Confucius (version 2.2), Robert Eno (translator), 2015, XII, 5, p 62.
} 
to cultivate harmonious relations with the others and with the nature ${ }^{27}$. Ren is the way of human conduct, the way in which humans social life go on, humanity. Man is supposed to love his fellow men and treat others as he does himself $^{28}$. It is the Confucian morality which is the highest principle of humanity.

Xinzhong Yao said that morality has been characteristic of Confucian theory and practice. It was on the foundation of Confucianism that various codes of moral life, rules of propriety, patterns of behavior and guide-lines for social and daily life were produced and enhanced. Confucianism underlined, and perhaps to a smaller extent continues to underline, the basic structure of society and community, to orient the life of the people and to define their moral standards and ethical ideals in most parts of East Asia ${ }^{29}$. This is the teaching in the main chapter (verses 4-6) of the Confucian classic, the Great Learning.

'(4) The ancients who wished to illustrate illustrious virtue throughout the kingdom, first ordered well their own states. Wishing to order well their states, they first regulated their families. Wishing to regulate their families, they first cultivated their persons. Wishing to cultivate their persons, they first rectified their hearts. Wishing to rectify their hearts, they first sought to be sincere in their thoughts. Wishing to be sincere in their thoughts, they first extended to the utmost their knowledge. Such extension of knowledge lay in the investigation of things.

(5) Things being investigated, knowledge became complete. Their knowledge being complete, their thoughts were sincere. Their thoughts being sincere, their hearts were then rectified. Their hearts being rectified, their persons were cultivated. Their persons being cultivated, their families were regulated. Their families being regulated, their states were rightly governed. Their states being rightly governed, the whole kingdom was made tranquil and happy. (6) From the Son of Heaven down to the mass of the people, all must consider the cultivation of the person the root of everything besides. ${ }^{30}$,

The prerequisite for achieving the fruits of self-cultivation is the necessity of freedom, because freedom is the center of dynamics for human existence. Freedom is a characteristic of self-identity and expression of humanity. The basis of any moral principle is the dignity of the human person endowed with reason and freedom of selfdetermination, but the human person also is vulnerable by nature. Individual freedom and self-determination must be related to the common good $^{31}$.

| The concept of freedom in Confucianism can-not be separated from what Sastrapratedja calls common good. Freedom in Confucianism is freedom within the boundaries and framework of social relations. Individuality is one element of happiness, but individual freedom must be limited, and the limit of individual freedom belongs to the other freedom. Thus individual freedom should not be allowed to detract from the freedom of others. When a person's individual freedom meets the freedom of others, we called it sociality. Individuality dissolves in sociality. The identity of 'I', 'you' and 'they' dissolves to become 'we', but their identity as an individual remains inherent.

Freedom contains the meaning of responsibility, order and involvement. Hence, it means recognition of plurality and diversity. The acknowledgment of plurality means the attitude of plurality. Freedom must be interpreted in a relational framework with others, where social responsibility must be possesed by every member of society. This is then formulated by Confucius as the great harmony. What Confucius wants with the great harmony only possibly occurs if humans individually base their life orientation to become morally noble beings (chun tzu). The exemplary person is one who is able to uphold the dignity of his_or her humanity (ren), and this means upholding human rights values. The self-realized human is one who develops civilized society. In the other words, the chun tzu human is an exemplar for human relationships.

The orientation of a chun tzu's life is not on what can be obtained from others, but on what can be done (given) and accommodated for others. Only a chun tzu human has the ability for transforming society towards peace. If there is righteousness in the heart, there will be beauty in the character. If there is beauty in the character, there will be harmony in the home. If there is harmony in the home, there will be order in the nation. If there is order in the nation, there will be peace in the world ${ }^{32}$. In fact, anyone can become a good Confucian as long as their behavior and attitude is in accordance with ren and his/her name. So, rectifying names is the correct way to realize the great harmony in reality and one of the solutions for socio-political problems.

27. Gong Dafei, 1991, p 314, Confucius Humanitarinist Ideas and the Contemporary International Community, in Confucianism and The Modernization of China, (Edited by Silke Krieger, Rolf Trauzettel), v. Hase \& Koehler Verlang Mainz, Germany.

${ }_{28}^{28}$. Gong Dafei, 1991, p 315.

29. Xinzhong Yao, 2005, p 32, An Introduction to Confucianism, Cambridge University Press.

30 . The Great Learning of Confucius, $\mathrm{p} 2$.

${ }^{31}$. M. Sastrapratedja, 1997, p 29, Violence, Justice, and Human Dignity, in The Human Person and Society (Edited by

Zhu Dasheng et all), The Council For Research in Values \& Philosophy, washington D.C. USA.

32. Smith, Huston, 1991, p 174, The World's Religions Our Great Wisdom Traditions, A Division of Harper Collins Publishers, Harper, San Francisco. 


\section{F. Conclusion}

Many scholars have observed that said that Confucian teachings can be considered as this worldly. This worldly in Confucianism means each person has to attempt to become a good person and able to establish good relationships with others in order to reach social harmony in their daily life.

Harmony in social life is a mutual agreement between all members of society. In harmony, there is diversity and tolerance. Both diversity and tolerance are built up in harmony. So, when we say keep diversity and keep tolerance, it means keep harmony too, because it automatically consits of diversity and tolerance. Therefore, it is correct when there is the enforcement of the rule of law and ethics as an effort to ensure the attainment of harmony in social life. This means that all members of society should play their role in accordance with the name which they possess.

The concept of the Confucian social harmony derives from the basic concept of humanity (ren) which is realized first with self-cultivation, then the family system and social system. Harmony is a logical consequence of applied Confucian ethics in social life. This harmony is based on ren as a fundamental principle of the whole thought of Confucianism. Humanity is placed within the framework of relationships with other human beings, so that ren is the ideal framework in human relationships. With such an understanding, then righteousness (yi), virtue (zhi) and popriety (li) should be applied in the context of a relationship between humans being.

A good relationship will develop if there is a division of roles and functions among members of the society. The meaning of the division of roles and functions is to increase harmony and solidarity among all of the members of society. It will improve effectiveness and efficiency so the progress of social and cultural work accelerates. For the individual, working means contributing and participating the cultural and social development processes. The division of roles and functions should be conducted in accordance with names carried.

Order, harmony and solidarity are prerequisite for arising the social cohesion in the community and the requirement for the realization of a society that is strong and independent that in the context of Confucianism is referred to as the great harmony. The order of social life of the community will only be realized if each individual aspires to the moral quality on ren (humanity), yi (righteousness), li (propriety), xiao (filial piety),_and zhong (loyalty). But, before people act, self-cultivation and rectifying names are the first tasks to be undertaken.

\section{References}

Chenyang Li, 2006, 584, The Confucian Ideal of Harmony, in Philosophy East and West, Volume 56, Number 4, October 2006, pp. The University of Hawai'i Press.

Cyrille J D Jawary, 2010, Les Trois Sagesses Chinoises, Taoisme, Confucianisme, Budhisme.

Damardjati Supadjar, 1996, Nawangsari, Yogyakarta.

Francesco Ademollo, 2011, The Cratylus of Plato A Commentary, Cambridge University Press, The Edinburgh Building, Cambridge, UK.

Gong Dafei, 1991, 314, Confucius Humanitarinist Ideas and the Contemporary International Community, in Confucianism and The Modernization of China, (Edited by Silke Krieger, Rolf Trauzettel), v. Hase \& Koehler Verlang Mainz, Germany.

John Knoblock, Xunzi, A Translation And Study of The Complete Works, Volume I Books 1-6, Stanford University Press, Stanford, California.

Kuno Lorenz and J. Mittelstrass, Mind, Vol. 76, No. 301 (Jan. 1967).

Lee Dian Rainey, 198, 2010, Confucius \& Confucianism, The Essentials, Blackwell, United Kingdom.

Loubna El Amine, 2015, Classical Confucian political thought : A new interpretation, Princeton University Press, Princeton, New Jersey.

M. Sastrapratedja, 1997: 29, Violence, Justice, and Human Dignity, dalam The Human Person and Society (Edited by Zhu Dasheng et all), The Council For Research in Values \& Philosophy, washington D.C. USA.

Notonagoro, 1997, Pancasila Secara Ilmiah Populer, Bumi Aksara, Jakarta.

Confucius, 2015, The Analects of Confucius (version 2.2), Robert Eno (translator).

Smith, Huston, 1991, 174, The World's Religions Our Great Wisdom Traditions, A Division of Harper Collins Publishers, Harper, San Francisco.

Setiawan, Chandra, 1998, 49, Kehadiran Agama Khonghucu Di Indonesia, Matakin, Jakarta.

Si Shu, 2012, Si Shu (Kitab Yang Empat), Kitab Suci Agama Khonghucu, Majelis Tinggi Agama Khonghucu Indonesia (MATAKIN), Jakarta.

The Great Learning of Confucius, this page copyright (c) 2001 Blackmask Online, http://www.blackmask.com. Accessed at December, 2018. 
Thomas Hosuck Kang, 1997, 109, Confucius and Confucianism, Questions and Answers, Confucian Publications, Washington, D.C.

Tsung-I Dow, 1995, The Twofold Phenomenon In Naming: A Reflection From The Confucian-Taoist Yin-Yang Dialectical, Monistic Perspective, in Anna-Teresa Tymieniecka, 1995, Heaven, Earth, And In-Between In The Harmony of Life, in the World Phenomenology Institute, Published under the Auspices of the World Institute for Advanced Phenomenological Research and Learning, A-T. Tymieniecka, President, SpringerScience+Business Media, B.V.

Tu Wei-Ming, Self-cultivation in Chinese philosophy, DOI, 10.4324/9780415249126-G014-1

Xinzhong Yao, 2005, An Introduction to Confucianism, Cambridge University Press, The Edinburgh Building, Cambridge, United Kingdom.

Xinzhong Yao, 1999, 4, Confucianism and its Modern Values: Confucian moral, educational and spiritual heritages revisited, Journal of Beliefs \& Values, Vol. 20, No. 1, 1999.

Yan, Heriyanto, 2005, 2. The history and legal position of Confucianism in post-independence Indonesia.s 